\title{
DAMPAK PERUBAHAN FUNGSI KAWASAN DAN POLA ADAPTASI MASYARAKATNYA DI KOTAWARINGIN TIMUR
}

\author{
THE IMPACT OF CHANGES IN AREA FUNCTION \\ AND PATTERNS OF COMMUNITY ADAPTATION IN \\ KOTAWARINGIN TIMUR
}

\author{
Moch Andri WP \\ BPNB Kalimantan Barat \\ Jl. Letjend Soetoyo, Pontianak \\ andrewp626@yahoo.co.id
}

Diterima 6 September 2017

Disetujui tanggal 17 November 2017

\begin{abstract}
Since the early 1980s, investments in oil palm plantations have been introduced and promoted by the government. Even before that, ie since the 1970s. But its significant development effort has only begun since the end of forest exploitation. Whether it's legal or illegal. Especially after the prohibition and control of forest exploitation activities. This paper is aimed to determine the impact of area function and patterrns of community adaptation at Kotawaringin Timur district. At a time when the rights of forest concessions are still rife, until the presence of expansion of oil palm plantations. The approach is done in two ways, namely macro and micro approach. The macro approach emphasizes more on the study of the structure and social institutions that exist in society. While the micro approach emphasizes more on the theoretical orientation of the adaptation process, that is historical and evolution of cultural. In general, this approach is aimed at understanding the past conditions when forest exploitation is still occurring, the socio-economic and cultural a change functions as a result of effect plantation development and adaptation patterns of society
\end{abstract}

Key words: forest exploitation, plantation expansion, and patterns of adaptation.

\begin{abstract}
ABSTRAK
Sejak awal tahun 1980-an, investasi-investasi di bidang perkebunan kelapa sawit memang sudah mulai dikenalkan dan digalakkan oleh pemerintah. Bahkan jauh sebelum itu, yaitu sejak tahun 1970an. Namun upaya pengembangannya yang signifikan justru baru dimulai sejak berakhirnya era pengusahaan hutan. Baik itu yang dilakukan secara legal maupun ilegal. Terutama setelah adanya larangan dan penertiban aktivitas-aktivitas pengusahaan hutan. Tulisan ini sendiri bertujuan untuk mengetahui dampak peralihan fungsi kawasan dan pola-pola adaptasi masyarakat di Kotawaringin Timur. Terutama sekali pada saat hak pengusahaan hutan masih marak terjadi, hingga hadirnya perluasan-perluasan perkebunan kelapa sawit. Pendekatan dilakukan dengan dua cara, yaitu pendekatan makro dan mikro. Pendekatan makro lebih menekankan pada telaah struktur dan institusi sosial yang ada di masyarakat. Sementara pendekatan mikro lebih menekankan pada orientasi teoritis dari adaptasi, yaitu sejarah dan evolusi budaya. Secara umum, pendekatan ini bertujuan untuk memahami kondisi masa lalu ketika pengusahaan hutan masih marak terjadi, perubahan fungsi-fungsi sosial ekonomi dan budaya sebagai akibat dari pengembangan perkebunan dan pola-pola adaptasi yang dilakukan masyarakat.
\end{abstract}

Kata kunci: pengusahaan hutan, ekspansi perkebunan, dan pola adaptasi. 


\section{A. PENDAHULUAN}

Pro dan kontra tentang hadirnya perkebunan-perkebunan besar sawit memang seperti tidak akan pernah berhenti. Terutama menyangkut alasan dari keberadaannya secara ekonomi pada satu sisi, dan secara ekologis pada sisi yang lain. Antara pemerintah sebagai pelaku sekaligus penentu kebijakan yang didukung oleh para pemilik modal, dan para pemerhati atau kelompok aktivis lingkungan.

Sejak awal 1980-an, investasi-investasi pada subsektor perkebunan kelapa sawit memang sudah mulai dikenalkan dan juga digalakkan oleh pemerintah. Bahkan mungkin jauh sebelum itu. Tetapi geliat dari upaya ini justru baru mulai dirasakan pada satu dekade atau sepuluh tahun kemudian. Salah satu indikatornya adalah laju perkembangan luas areal lahan-lahan perkebunan kelapa sawit di Indonesia yang pada awal 1990-an sudah mencapai lebih dari 1.066.667 hektar, atau setara dengan empat kali lipat jumlahnya dari awal tahun 1980-an yang hanya mencapai 294.560 hektar (PDBI 1998, dalam Abdul Hakim Basyar, 2001;3).

Seperti halnya di Sumatera, komoditas kelapa sawit juga mulai dikenalkan dan dikembangkan di Kalimantan sejak Pelita III, atau sekitar awal tahun 1980-an. Namun upaya yang signifikan justru baru dimulai sejak berakhirnya era kayu hutan sebagai salah satu komoditas masyarakat yang menjadi primadona pada saat itu. Terutama sekali ketika kasus-kasus pembalakan hutan dan perdagangan kayu ilegal yang begitu marak terjadi pada awal-awal 1990-an hingga pertengahan 2000 mulai meredup, seiring dengan keluarnya larangan dan penertiban aktivitas-aktivitas pengusahaan kayu hutan. ${ }^{1}$ Terutama setelah dua persoalan utama sektor

1 Terutama setelah keluarnya Instruksi Presiden No. 4/2005 tentang Pemberantasan Penebangan Kayu secara llegal di Kawasan Hutan dan Peredarannya di Seluruh Wilayah Republik Indonesia. kehutanan Indonesia pada masa itu, yaitu pembalakan dan perdagangan kayu ilegal telah mengakibatkan hilangnya potensi pendapatan negara dari sektor pajak (Asia Pulse dan Media Indonesia dalam Obidzinski, Krystof et al., 2016:1). Sehingga sejak saat itu pula upaya-upaya pengembangan dan perluasan investasi pada subsektor perkebunan khususnya kelapa sawit mulai menunjukkan geliatnya yang signifikan. Hal ini mulai tampak pada awal-awal rencana dari proses pengembangan dan perluasannya di Kalimantan, khususnya Kalimantan Tengah. Di mana jumlah realisasi penyediaan areal lahan-lahan untuk perkebunan besar hingga awal permulaan Pelita VI atau tahun 1998 telah mencapai 2.213.804 hektar (statistik Direk. Jendral Inventarisasi Tata Guna Hutan dan Kebun tahun 1997/1998, dalam Abdul Hakim Basyar, 2001:2). Menariknya, angka ini ternyata menjadi yang tertinggi, atau lebih dari $25 \%$ jumlah realisasi penyediaan areal lahan-lahan untuk perkebunan besar di Indonesia yang saat itu luasnya hanya mencapai 8.204.524,09 hektar.

Sejalan dengan itu, jumlah luas areal lahan-lahan perkebunan besar kelapa sawit di Kalimantan Tengah memang menunjukkan angka yang tidak jauh berbeda hingga saat ini. Pada medio tahun 2014-2016 saja, jumlah luas areal lahan perkebunan kelapa sawit di Kalimantan Tengah mencapai 1.115.933 hektar, dengan jumlah total produksi keseluruhan mencapai sekitar 3.158.239 ton (Subiyantoro et al., 2015:9). Meskipun sudah tidak lagi menjadi angka yang tertinggi, tetapi keberadaannya tentu sudah dapat mewakili gambaran dari berbagai polemik yang ditimbulkan oleh karena adanya perubahan pola-pola ruang kawasan.

Polemik-polemik dari persoalan seperti dampak ekologis pelepasan kawasan, perubahan pola-pola ruang pemanfaatan dan akses masyarakat terhadap sumberdaya alam, hingga pada maraknya kasus-kasus konflik tenurial antara masyarakat dan 
pihak perusahaan adalah isyarat nyata dari perubahan pola ruang dan fungsi kawasan yang terjadi. Tulisan ini sendiri akan menelaah gambaran perubahan dan pola-pola adaptasi masyarakat akibat beralihnya fungsi kawasan. Terutama yang ditujukan pada upaya-upaya pengembangan dan perluasannya di Kotawaringin Timur setelah adanya larangan dan penertiban aktivitasaktivitas dari pengusahaan hutan.

Telaah dalam tulisan ini sendiri bertujuan untuk mengidentifikasi dan menjelaskan secara makro 1) perubahan-perubahan yang terjadi akibat pengalihan fungsi kawasan dan 2) aktivitas-aktivitas adaptasi yang dilakukan masyarakat sebagai akibat dari beralihnya fungsi ruang kawasan tersebut. Meski telaah ini merupakan bagian dari penelitian yang dilaksanakan pada akhir tahun 2012, namun fokus tujuannya masih tetap relevan untuk ditulis saat ini.

Ruang pembahasan tulisan ini dibatasi pada kondisi dari hilang dan bergantinya objek-objek sosial dan budaya di masyarakat. Terutama menyangkut 1) tradisi-tradisi sistem pemanfaatan dan pengelolaan yang terbentuk, serta 2) dampaknya bagi keberlangsungan sosial ekonomi dan budaya masyarakat sekitar kawasan.

Perubahan dan adaptasi adalah dua hal yang saling terkait, terutama menyangkut perubahan yang terjadi di masyarakat. Secara umum ada dua bentuk perubahan yang selama ini kita kenal di masyarakat, yaitu yang direkayasa atau disengaja, dan yang terjadi secara alami. Perubahan juga kemudian terbagi lagi atas dua katagori, yaitu yang terjadi secara bertahap atau gradual, dan yang terjadi secara drastis atau cepat (Soekanto, 2000:333-352). Dalam pengertian yang sama ini kemudian kita mengenal adanya istilah evolusi dan revolusi. Secara sosiologis, evolusi adalah pengertian dari adanya peningkatan diferensiasi sekaligus spesialisasi. Sementara revolusi adalah suatu proses dari perubahan yang berlangsung secara cepat hingga pada dasar-dasar dari suatu (sistem) masyarakat (Soekanto, 1993: 151. 384).

Dalam konteks pengembangan dan juga perluasan areal lahan-lahan perkebunan, tidak semua perubahan terjadi secara gradual, bertahap atau terencana. Namun juga banyak yang terjadi secara cepat, mendasar dan tidak direncanakan. Karena hal ini menyangkut investasi-investasi yang direalisasikan melalui pembukaan areal lahan-lahan perkebunan dan fasilitas infrastruktur pendukungnya dalam suatu kawasan. Kondisi ini tentu tidak lagi semata berdampak pada kewilayahan, yaitu struktur dan pola ruang kawasannya. Melainkan juga berdampak pada kondisi sosial, ekonomi dan budaya di masyarakat. Baik itu yang menyangkut aksesnya pada sumbersumberdaya alam dan lahan, maupun tradisi-tradisi dalam upaya pengelolaannya. Hingga pada gilirannya masyarakat tentu akan dihadapkan pada suatu perubahan yang menuntut akan adanya adaptasi atau penyesuaian.

Secara harfiah, adaptasi adalah pengertian dari proses penyesuaian ${ }^{2}$. Karena adaptasi di sini menyangkut komunitas, maka pengertiannya ini kemudian melibatkan banyak aspek dari unsur-unsurnya yang ada pada suatu komunitas atau masyarakat. Sebab itu, adaptasi di sini adalah menyangkut cara yang dilakukan oleh komunitas atau masyarakat secara ekologi budaya dalam upaya menyesuaikan dengan perubahanperubahan yang terjadi.

Ekologi budaya di sini adalah pembahasan yang menitikberatkan pada dua konsep yang utama yaitu, lingkungan dan (aktivitas) adaptasi. Hal tersebut karena lingkungan dan aktivitas budaya merupakan bagian dari sistem yang saling berhubungan satu sama lain (Kaplan dan Maners,

2 diunduh dari Kamus Besar Bahasa Indonesia dalam Jaringan, pada 10 Juli 2017. 
2002:104). Lingkungan dalam konteks ekologi-budaya di sini tidak lagi semata dipahami sebagai benda alami, dan secara faktual juga tidak dapat digambarkan secara objektif. Karena lebih menyangkut persepsi. Lingkungan di sini lebih merupakan seperangkat pemahamanan tentang produkproduk kebudayaan suatu komunitas atau masyarakat. Relasi antara komunitas dengan lingkungan hanya akan dapat dipahami bila kita menyimak dan mengetahui caracara pengorganisasian lingkungan dalam katagori-katagori verbal dari mereka yang menggunakannya (Kaplan dan Maners, 2002: 104-105).

Manusia itu pada dasarnya akan selalu berinteraksi secara simultan dengan lingkungannya. Proses dari interaksi tersebut, menurut Berger dan Luckman dilakukan dalam dua jenis bentuk kesadaran; objektif dan subjektif (Berger dan Thomas Luckman, 1990:1). Kesadaran objektif adalah kesadaran yang menempatkan kenyataan atau realitas sosial yang ada itu berada dalam keberadaannya sendiri, tidak tergantung pada kehendak manusia. Sementara kesadaran subjektif lebih menempatkan bahwa kenyataan atau realitas sosial akan memiliki makna atau nilai-nilainya yang lebih nyata atau spesifik sesuai dengan apa yang telah ditafsirkan atau diinternalisasi oleh masyarakatnya sendiri. Sebab itu, interaksi menurutnya akan selalu dilakukan dalam tiga caranya yang juga selalu dialektis antar satu sama lain, yaitu eksternalisasi, objektivasi dan juga internalisasi. Eksternalisasi adalah proses adaptasi (interaksi) terhadap kondisi sosial dan budaya yang telah menjadi rujukanrujukan sosial bagi masyarakat sebelumnya. Objektivasi adalah proses interaksi atau adaptasi yang dibangun atas dasar suatu kesadaran bahwa setiap kebudayaan memiliki nilai-nilainya yang positif. Sementara internalisasi lebih menyangkut pada suatu proses identifikasi diri untuk bisa menjadi bagian dari realitas sosio-kultural tersebut (Berger dan Thomas Luckman, 1990:1 dan 28-65).

Penulisan ini merupakan bagian dari penelitian yang dilaksanakan di Kotawaringin Timur, Kalimantan Tengah akhir tahun 2012. Pemilihan lokasi lebih banyak didasarkan pada pertimbangan bahwa Kotawaringin Timur ini merupakan daerah dengan jumlah areal lahan perkebunan sawit terluas di Kalimantan Tengah pada tahun 2012, yaitu mencapai 520.000 hektar (Buletin Bank Indonesia, 2012). Bahkan hingga tahun 2016, estimasi dari jumlah total luasnya diperkirakan telah mencapai sekitar 1.075.295 hektar (Subiyantoro, et al. (ed.), 2015).

Pendekatan penulisan dilakukan dalam dua cara, yaitu secara makro dan mikro. Pendekatan makro lebih menekankan kepada telaah struktur dan institusi-institusi sosialnya yang ada di masyarakat. Terutama guna mempelajari dan memahami struktur masyarakat secara luas, baik tanpa atau dengan memperhatikan fungsi-fungsinya terhadap strukturnya yang lain. Sementara pendekatan mikro lebih menekankan pada orientasi teoritis dari proses adaptasi, yaitu secara historis dan evolusi kulltural. Pendekatan ini secara antropologi kerap juga disebut dengan ekologi kultural. Satu ciri dalam pendekatan ekologi budaya atau ekologi kultural adalah perhatiannya terhadap proses adaptasi yang berada pada dua tataran, yaitu cara sistem budaya beradaptasi terhadap lingkungannya, dan cara-cara institusi dalam suatu budaya itu beradaptasi (Kaplan dan Manners, 2002:102). Oleh karena itu, bentuk-bentuk pertanyaan yang diajukan kerap kali cenderung lebih bersifat fungsional dan historis.

Data-data sekunder penelitian diperoleh melalui telaah dokumen-dokumen terkait dengan berita acara penyelesaian kasus konflik lahan di sekitar perkebunan kelapa sawit, dan statistik daerah. Sementara datadata primer diperoleh melalui wawancara terhadap masyarakat sekitar areal per- 
kebunan, mantan pekerja saat pembukaan awal lahan (blocking area), aparat kepolisian, demang $^{3}$ dan juga oknum yang terlibat dalam kasus perkara sengketa lahan antara masyarakat dan pihak perusahaan. Terutama sekali untuk mengetahui dan memahami kondisi pada masa lalu ketika hasil kayu hutan masih menjadi sumber ekonomi primadona di masyarakat, dampak dari adanya larangan atau penertiban aktivitas pengusahaan kayu-kayu hutan, serta dampak dari pengalihan fungsi atau pelepasan kawasan hutan menjadi lahanlahan perkebunan, utamanya terhadap masyarakat sekitar.

\section{B. HASIL DAN BAHASAN}

Kotawaringin Timur merupakan satu dari 14 kabupaten-kota yang berada dalam administrasi wilayah Kalimantan Tengah. Secara geografis, letak Kotawaringin Timur berbatasan langsung dengan Laut Jawa di sebelah Selatan, Kabupaten Katingan di Sebelah Timur dan juga Utara serta Kabupaten Seruyan di sebelah Barat. Dengan luas wilayah yang mencapai sekitar 16.796 $\mathrm{km}^{2}$, sebagian dari Kotawaringin Timur merupakan dataran rendah, yaitu sekitar 200 meter di atas permukaan laut. Sementara pada sebagiannya lagi merupakan daerah dengan ciri-ciri pedalaman atau inland.

Jumlah penduduk Kotawaringin Timur ini sendiri mencapai sekitar 397.057 jiwa pada tahun 2011, atau setara dengan rata-rata 27 jiwa per kilometer persegi tingkat kepadatan penduduknya. Dari jumlah tersebut, $47 \%$ diantaranya atau 187.706 jiwa merupakan usia 15 tahun ke atas yang bekerja pada jenis lapangan usaha utama tertentu, di mana 50\% diantaranya, atau sekitar 98.634 jiwa terserap pada sektor-sektor usaha pertanian,

3 Demang merupakan jabatan ketua adat wilayah setingkat kecamatan. Salah satu dari fungsi demang ini sendiri adalah membantu persoalan-persoalan yang terkait dengan adat di masyarakat. terutama sekali subsektor perkebunan. Sementara penduduk usia 15 tahun ke atas lainnya yang sedang tidak bekerja atau menjadi pengangguran mencapai 7.476 jiwa, atau setara dengan 1,9\% dari jumlah penduduk Kotawaringin Timur pada saat itu. (BPS Kalteng, $2012 ; 1-4)$.

Jumlah penduduk yang bekerja pada sektor-sektor usaha pertanian, khususnya subsektor perkebunan ini merupakan gambaran dari struktur masyarakat di Kotawaringin Timur yang terbentuk saat itu. Terutama setelah adanya larangan aktivitasaktivitas pengusahaan kayu hutan, atau setelah masuknya ekspansi perkebunanperkebunan besar sawit. Karena jauh sebelum itu, sebagian besar masyarakat Kotawaringin Timur, khususnya yang berada pada wilayah-wilayah pedalaman atau pedesaan banyak juga yang masih dapat mengakses ke sumber-sumber daya alam sekitar. Termasuk juga melakukan pengusahaan hasil hutan sebagai bagian dari aktivitas usaha ekonomi utama.

\section{Era Komoditas Kayu Hutan}

Era sebelum masuknya ekspansi perkebunan-perkebunan besar sawit merupakan jaman di mana sebagian besar kehidupan sosial dan ekonomi masyarakat Kotawaringin Timur itu lebih banyak dipengaruhi oleh akses ke sumber-sumber daya alam dan lahan sekitar. Termasuk dalam cara mereka saat itu memeroleh income cash atau pendapatan tunai melalui aktivitas-aktivitas pengusahaan hasil hutan, baik itu hasil kayu maupun nonkayu. Pada era ini, masyarakat masih begitu kental dengan tradisi-tradisi perladangan berpindah atau berotasi. Bentuk dari tradisi-tradisi lokal yang dalam pelaksanaannya biasa dipimpin oleh seorang kepala padang sebagai pengatur. Berbeda dengan status demang atau kepala adat, kepala padang ini merupakan seorang tokoh yang oleh karena pengalaman, pengetahuan dan juga kemampuannya kemudian 
memiliki wewenang untuk mengatur proses perladangan komunitas dalam satu areal kawasan perladangan tertentu. Kawasan dimaksud biasanya setara dengan areal wilayah pemukiman setingkat kampung dan atau desa. ${ }^{4}$ Misalnya dalam hal menentukan, proses dan waktu hari pelaksanaan, lokasi dan juga batas-batas dari areal perladangan satu sama lain anggota. Termasuk juga dalam menentukan pengalihan hak atas lahan dari bekas perladangan suatu anggota kepada anggota yang lain, jika itu dianggap telah ditelantarkan oleh pemiliknya. Pengertian ditelantarkan dimaksud pada umumnya berlaku dalam kurun waktu tertentu yang telah disepakati di antara mereka. ${ }^{5}$

Meskipun itu dilakukan dalam caracaranya yang sederhana, yaitu dengan pola perladangan berpindah, tetapi tradisi-tradisi lokal seperti ini justru menjadi bagian dari pola-pola subsistensi pertanian pangan mereka saat itu. Karena pola perladangan berpindah mereka ini tidak semata merupakan pelaksanaan dari tradisi-tradisi komunitas. Melainkan juga menjadi bagian dari upaya mereka menjaga hubungan antara sistem sosial dan ekonomi suatu komunitas dengan lingkungannya. Tentu akan sangat sulit untuk dapat tergantikan, karena hal tersebut juga menyangkut keberlangsungan sosial dan ekonomi suatu komunitas. Tidak heran, meski banyak dari mereka yang terlibat dalam aktivitas pengusahaan hutan, namun tradisi-tradisi perladangan berpindah ini tetap berlangsung atau tidak ditinggalkan oleh mereka pada saat itu.

4 Kampung di Kalimantan itu umumnya merujuk pada kesatuan wilayah pemukiman yang terbentuk oleh karena sejarah dalam pembukaan lahan-lahan pemukiman pada masa lalu, atau karena ikatan kekerabatan yang dekat antar sesama para pemukimnya. Sementara desa adalah wilayah administrasi pemerintahan terkecil yang terdiri dari beberapa kampung atau pemukiman yang dahulu dikenal dengan nama bawang, lepu' uma', apo' dan sebagainya.

5 Wewenang untuk mengalihkan hak akses lahan suatu anggota kepada anggota yang lainnya ini kemudian membuat peran kepala padang menjadi vital dalam proses ganti rugi pembukaan areal lahan-lahan perkebunan selanjutnya.
Selain para pekerja yang berasal dari luar daerah, maraknya aktivitas-aktivitas pengusahaan kayu di hutan juga banyak melibatkan masyarakat sekitar. Meski dalam perannya yang berbeda-beda antar satu sama lain. Ada yang sekedar menjadi penebang kayu, buruh angkut, perintis jalan-jalan di hutan, menjadi penyedia jasa angkutan hasil kayu, penyedia barang-barang kebutuhan bagi para pekerja yang bermalam di hutan, hingga pada peran-peran pendukung yang lain di pusat-pusat kota atau pasar yang juga menerima dampak dari peredaran uang cash hasil usaha kayu-kayu di hutan dan sebagainya.

Sebagaimana pengaruhnya pada tradisitradisi ladang berpindah, pola peredaran uang hasil pengusahaan kayu-kayu di hutan ini ternyata juga tidak signifikan pada kontribusinya terhadap pendapatan asli daerah di Kotawaringin Timur. ${ }^{6}$ Hal ini karena sebagian dari aktivitas pengusahaan hutan ini memang dilakukan secara ilegal.

Satu hal yang mungkin paling menarik untuk bisa menggambarkan kondisi pada saat itu, atau saat sebelum tergantikan oleh kehadiran dari perkebunan-perkebunan besar kelapa sawit adalah dampaknya terhadap geliat aktivitas kehidupan pasarpasar di pusat Kota Sampit, Ibu Kota Kabupaten Kotawaringin Timur. Selain memang sebagai kota pelabuhan, aktivitas dari pusat-pusat pertokoan dan pasar tradisional di Kota Sampit saat itu ternyata begitu hidup. Terutama karena aktivitasaktivitasnya di malam hari, saat para pekerja kayu hutan dari luar daerah, atau juga yang berasal dari daerah-daerah sekitar mulai menghabiskan waktu dari setengah malamnya untuk mengganti kepenatan suasana kerja, menikmati sajian kuliner atau berbelanja barang kebutuhan selama di hutan-hutan. Lambat laun, tidak saja

6 Hasil analisis sejumlah informasi yang diperoleh dari para informan. 
hanya para pekerja dari hutan, masyarakat yang memang tidak terlibat langsung dalam aktivitas-aktivitas di hutan pun juga mulai turut meramaikan kehidupan pasar di malam hari. Sehingga aktivitasaktivitas pasar menjadi berkembang. Tidak hanya menyediakan kuliner, namun juga menyediakan barang-barang kebutuhan yang lain, seperti sandang dan juga fasilitasfasilitas hiburan. Cukup lengkap jika suasana pasar ini kemudian disebut dengan pasar malam, atau yang populer dan kerap kali disebut oleh mereka, para pendatang dari Pulau Jawa sebagai bauran.

Salah satu geliat dari kehidupan pasar malam yang paling menonjol saat itu adalah keberadaan warung-warung tendanya yang menyediakan sajian kuliner bagi para pengunjung. Begitu banyaknya warung-warung tenda berjajar di sepanjang jalan di tengah pasar, hampir tidak ada dari pelayanpelayannya yang memiliki waktu jeda untuk beristirahat disela-sela aktivitasnya pada saat itu. Silih berganti para pengunjung warung tenda adalah bagian dari rutinitas yang dihadapi mereka setiap malam. Termasuk yang menurut dari banyak informasi, beberapa dari mereka ini ternyata ada juga yang bersedia atau mau turut menemani para pelanggan setelah pasar malam menghentikan aktivitasnya. Sebuah fenomena dari kondisi sosial yang secara sosiologis lazim terjadi pada daerah-daerah tertentu yang menerima dampak dari maraknya transaksi peredaran uang dari hasil pengusahaan kayu-kayu hutan saat itu. Terutama mereka, para pelanggan kelas pekerja yang mayoritas memang berasal dari luar-luar daerah. Meski tidak sedikit juga yang kemudian berasal dari daerah-daerah sekitar.

Geliat ekonomi pasar seperti ini ternyata tidak semata ditunjukkan oleh berkembangnya sektor-sektor informal di malam hari. Namun juga pada sektor-sektor ekonomi formal. Salah satunya adalah ditunjukkan dengan banyaknya fasilitas-fasilitas per- bankan, baik pemerintah maupun swasta yang turut mengembangkan kantor-kantor jasa pelayanan hingga ke wilayah-wilayah Kota Sampit. Terutama melalui pendirian kantor-kantor cabang, kantor unit dan atau kantor cabang pembantu. Karena jauh sebelum Pemerintah Kabupaten mulai gencar melakukan perluasan-perluasan investasi pada subsektor perkebunan khususnya kelapa sawit, fasilitas-fasilitas perbankan seperti ini ternyata memang telah lama ada. Artinya, jauh sebelum Kabupaten Kotawaringin Timur memiliki angka pertumbuhan ekonomi tertinggi se Provinsi Kalimantan Tengah pada tahun 2011, terutama melalui upayaupaya perluasan investasinya dalam subsektor perkebunan kelapa sawit, sejumlah fasilitas dari perbankan ini memang telah banyak berdiri di Kota Sampit. Lebih lanjut tentang pertumbuhan ekonomi dimaksud ini akan dibahas pada sub pembahasan selanjutnya.

Demikian halnya dengan geliat aktivitas dari kehidupan masyarakat lokal di banyak daerah pedesaan dan pedalaman. Selain memang masih bisa mengakses dan mengelola areal lahan-lahan sekitar, sebagian kaum lelaki dewasanya juga banyak yang terlibat dalam aktivitas menebang kayu-kayu di hutan. Baik itu yang resmi atau legal, yaitu dengan cara bekerja pada proyek land clearing perusahaan yang telah memeroleh izin pemanfaatan kayu untuk usaha perkebunan, ${ }^{7}$ atau terlibat dalam kelompok-kelompok kecil yang melakukan usaha penebangan kayu secara ilegal. Segala aktivitas yang berhubungan dengan pengusahaan kayukayu di hutan pada saat itu memang relatif besar pengaruhnya terhadap kehidupan sosial ekonomi masyarakat. Bahkan ada satu

7 Beberapa perusahan perkebunan kelapa sawit di Kalimantan Tengah sebenarnya sudah mulai ada yang mendapatkan izin usaha atau konsesi perkebunan sejak awal tahun 2000-an. Namun beberapa diantaranya justru tidak pernah menindaklanjuti dengan realisasi penanaman, atau hanya melakukan pemanfaatan dari batang tumbuh atau kayu-kayu yang berada di atas areal lahannya. 
bentuk ungkapan di masyarakat yang cukup populer untuk menandai kondisi saat itu, "mencari uang ternyata semudah menebang pohon di hutan".

Demikian gambaran kondisi sosial ekonomi dan budaya pada era komoditas hutan. Hingga perubahan itu kemudian muncul seiring dengan berakhirnya konsesi hutan, adanya larangan dan penertiban aktivitasaktivitas penebangan kayu di hutan secara ilegal, dan hadirnya ekspansi-ekspansi perkebunan besar sawit.

\section{Ekspansi Perkebunan Sawit}

Hadirnya pola-pola perkebunan besar kelapa sawit di Kalimantan, baik swasta maupun negara memang sudah dimulai sejak dekade tahun 1990-an. Bahkan jauh sebelum itu, sejak awal 1980-an, ketika kelapa sawit mulai dikenalkan secara luas sebagai salah satu komoditas utama tanaman perkebunan. Tetapi jumlah dan luas arealnya tentu masih tidak signifikan dibanding luas dari areal konsesi-konsesi pengusahaan hutan yang ada. Termasuk luas dari hutanhutan yang mengalami kerusakan akibat pembalakan liar yang terjadi selama lebih dari satu dekade, yaitu sejak awal tahun 1990-an hingga pertengahan $2000 .^{8}$ Seiring dengan persoalan ekologis dari kerusakankerusakan hutan yang terjadi saat itu, kelapa sawit kemudian muncul sebagai komoditas pengganti dengan wajahnya yang seakan humanis. Karena belakangan justru diketahui bahwa perkebunan dan upaya-upaya perluasannya ternyata juga kerap membawa persoalan ekologis yang hampir sama.

Konsesi perkebunan memang kerap memunculkan persoalan yang tidak kalah lebih rumit dari konsesi pengusahaan hu-

8 Berakhirnya era pengusahaan hutan itu salah satunya ditandai dengan kenaikan yang siginifikan jumlah total luas areal lahan-lahan perkebunan sawit di Indonesia, dari 5.453.817 hektar pada tahun 2005, menjadi 6.594.914 hektar pada tahun 2006 , atau setara dengan $21 \%$ yaitu sekitar 1.141.097 hektar dalam kurun waktu hanya satu tahun (BPS Daerah Kalimantan Tengah). tan. Tidak semata menyangkut fungsi dari kawasannya yang memang berubah. Namun juga menyangkut pola peralihannya dari sistem kelola tradisional masyarakat ke arah sistem pengelolaan modern, atau perkebunan-perkebunan besar. Sehingga sebagian masyarakat yang sejatinya terbiasa dengan tradisi dan kultur pengelolaan lahan secara sederhana, lalu menjadi gagap untuk mengikuti bentuk-bentuk perubahan yang terjadi.

Tidak hanya itu, hal yang paling mendasar dari adanya pengalihan fungsi kawasan adalah eliminasi hak masyarakat atas ruangruang kelola sekitar. Masyarakat tentu tidak lagi memiliki pola subsistensi ekonomi yang berasal dari sumber-sumber daya alam dan lahan sekitar. Mereka terpaksa harus menjadi bagian yang terpisah dari areal-areal sekitar yang pernah mereka miliki. Sehingga yang kerap kali muncul dan selalu menjadi bagian dari pengembangan areal-areal perkebunan besar kelapa sawit di Kotawaringin Timur adalah persoalan-persoalan konflik tenurial antara perusahaan dan masyarakat sekitar perkebunan.

Hampir di setiap pengembangan arealareal perkebunan kelapa sawit memang kerap kali dilingkupi oleh persoalan antara masyarakat dengan perusahaan. Terutama menyangkut areal lahan-lahan yang digunakan. Tetapi tidak semua kasus selalu melibatkan masyarakat secara luas. Beberapa ternyata hanya melibatkan individu dan atau perorangan. Meski demikian, persoalan menjadi rumit dan berlaru-larut karena senantiasa dipicu oleh ancaman atas subsistensi ekonomi, dan terkait dengan sistem tenurial yang ada dan berlaku pada suatu komunitas atau masyarakat ${ }^{9}$ Sehingga persoalan menjadi rumit dan berlarut-larut. Seperti berlarut-larutnya persoalan ganti

9 Hak untuk menguasai, memanfaatkan, mengelola dan bahkan mengalihkan, baik secara perorangan maupun kelompok yang diakui secara tradisi oleh komunitas. 
rugi nilai garapan lahan, anggapan adanya pencaplokan lahan oleh perusahaan, pembukaan areal-areal perkebunan yang dianggap akan menghilangkan kawasan primer masyarakat dan lain sebagainya.

Setelah keluarnya larangan atas aktivitas-aktivitas penebangan kayu di hutan dan dihentikannya konsesi-konsesi hak pengusahaan hutan oleh pemerintah, secara tidak langsung memang berdampak pada kehidupan sosial ekonomi masyarakat. Tetapi, kondisi yang tercipta saat itu masih memungkinkan mereka untuk dapat mengakses dan memanfaatkan hasil-hasil hutan. Baik hasil kayu maupun non kayu, sekalipun hanya sebatas untuk pemenuhan kebutuhan sehari-hari. Sementara dengan masuknya perkebunan-perkebunan besar sawit justru dirasa telah menghilangkan hampir semua akses masyarakat atas ruangruang kelola sekitar. Baik itu areal hutan alam, areal hutan buah-buahan, sungai atau sumber-sumber daya air, areal kawasan perladangan, areal pemanfaatan tradisional, kebun dan lain sebagainya. Sehingga tidak heran jika tuntutan-tuntutan ganti rugi atas hilangnya akses atas ruang-ruang kelola masyarakat ini menjadi persoalan yang kerap berlarut-larut melingkupi hadirnya perkebunan-perkebunan besar kelapa sawit di Kotawaringin timur. Meski sebagian dari latar kasusnya itu lebih banyak dilingkupi oleh banyaknya oknum-oknum kepentingan, baik individu atau kelompok yang selalu berusaha mengambil kesempatan untuk bisa memeroleh keuntungan. Baik pada saat proses penerbitan izin prinsip dan lokasi yang melibatkan banyak oknum pejabat pemerintah daerah, saat mendapatkan bukti perolehan atas tanah atau pelepasan hak kelola lahan yang juga banyak melibatkan oknum perangkat desa, adat dan tokoh masyarakat lain, hingga pada saat proses perintisan atau blocking area lahan kebun dan sebagainya. Termasuk beberapa kasus, baik itu secara individu ataupun kelompok yang mengajukan tuntutan ganti rugi lahan justru setelah penananam areal kebun dilaksanakan. Sebagai contoh adalah kasus-kasus yang saat proses penelitian ini dilaksanakan sedang dialami oleh perusahaan perkebunan $\mathrm{PT}$ AB dan AWL. ${ }^{10}$

Kasus-kasus seperti ini memang tidak sepenuhnya salah masyarakat. Karena keberadaan oknum-oknum tertentu yang selalu saja berusaha mengambil keuntungan dalam setiap kesempatan ini memang relatif lebih banyak disebabkan oleh kebijakan yang tidak pernah berpihak pada masyarakat sekitar. Jangankan untuk mendapatkan persetujuan awal dari masyarakat. Untuk mendapatkan informasi terkait dengan masuknya perusahaan perkebunan kelapa sawit itu saja baru diperoleh oleh sebagian masyarakat sekitar justru saat proses perintisan lahan sedang berlangsung atau dilaksanakan. Terutama saat perintisan atau blocking area dari lahan-lahan yang akan menjadi areal perkebunan itu harus bersentuhan langsung dengan keberadaan lahan-lahan milik masyarakat. Kondisi ini tentu telah mengisyaratkan adanya fakta bahwa terbitnya izin-izin usaha dari perkebunan yang mensyaratkan adanya izin prinsip, lokasi, amdal, dan bukti perolehan atas lahan pada saat itu memang tidak lagi berjalan sebagaimana mestinya.

Meski demikian, tetaplah harus diakui bahwa tidak semua ekspansi-ekspansi perkebunan besar kelapa sawit semata menghasilkan persoalan ekologis dan fungsi kelola kawasan. Seperti yang telah disinggung pada awal-awal pembahasan, salah satu dampak dari pembangunan dan juga perluasan areal lahan perkebunan besar kelapa sawit adalah masuknya arus modal investasi, faktor-faktor produksi dan penyerapan tenaga kerja daerah. Sehingga dampaknya secara makro adalah adanya angka pertumbuhan ekonomi

10 Salah satu perusahaan besar swasta yang telah memeroleh konsesi-konsesi lahan perkebunan di Kotawaringin Timur. 
yang cukup signifikan di Kotawaringin Timur.

\section{Dampak Ekonomi}

Selama kurun waktu lima tahun hingga 2011, kecuali pada tahun 2009 angka pertumbuhan ekonomi Kotawaringin Timur ternyata telah mengalami peningkatan yang cukup pesat, yaitu dari $6,27 \%$ pada tahun 2007 menjadi 7,7\% pada tahun 2011. Angka pertumbuhan ekonomi pada tahun 2011 ini ternyata juga menjadi yang tertinggi dari rata-rata pertumbuhan ekonomi di Provinsi Kalimantan Tengah pada saat itu (Buletin Bank Indonesia, 2012).

Tingginya angka pertumbuhan ekonomi di Kotawaringin Timur ini secara berturutturut ditopang oleh angka pertumbuhan subsektor utama yaitu perkebunan, industri dan jasa perdagangan. Pertumbuhan ketiga subsektor ini telah menyumbangkan angka kontribusi terbesar dalam pembentukan angka PDRB (Produk Domestik Regional Bruto) yang pada gilirannya juga memengaruhi peningkatan laju dari pertumbuhan ekonomi Kotawaringin Timur. Tidak heran jika dalam kurun waktu lima tahun terakhir, nilai angka PDRB Kotawaringin Timur ini mengalami peningkatan hingga dua kali lipat dari tahun 2007. Sementara angka rata-rata pendapatan perkapitanya meningkat satu setengah kali lipat dari awal tahun yang sama, yaitu tahun 2007. ${ }^{11}$

Sebagai ukuran produktivitas dari seluruh barang dan jasa yang dihasilkan, nilai PDRB Atas Dasar Harga Berlaku Kotawaringin Timur merupakan angka yang tertinggi sekabupaten-kota Kalimantan Tengah. Demikian juga dengan angka PDRB perkapita yang mencerminkan nilai produktivitas tiap-tiap penduduk di suatu wilayah. Nilainya saat itu juga menunjukkan

11 Statistik Daerah Kotawaringin Timur dalam Kajian Ekonomi Regional Provinsi Kalimantan Tengah, Triwulan III, Buletin Bank Indonesia, 2012:19). angka di atas rata-rata Kalimantan Tengah. Besaran PDRB Kotawaringin Timur tahun 2011 mencapai sekitar 9,25 triliun rupiah, atau setara 20,71\% dari angka nilai total PDRB seluruh kabupaten kota seKalimantan Tengah (Badan Pusat Statistik daerah kalimantan Tengah, 2012: 406). Berikut perbandingan angka PDRB Kotawaringin Timur dengan empat kabupaten induk dan Palangkaraya.

Tabel 1. Perbandingan PDRB Lima Wilayah Kabupaten Induk dan Kota Palangkaraya

\begin{tabular}{cccc}
\hline Urain & $\mathbf{2 0 0 9}$ & $\mathbf{2 0 1 0}$ & $\mathbf{2 0 1 1}$ \\
\hline \multicolumn{1}{c}{$\boldsymbol{P D R B}$ ADHB (juta $\boldsymbol{R p}$ ) } \\
\hline $\mathrm{Kbr}$ & $4.063 .148,6$ & $4.509 .799,5$ & $5.129 .158,0$ \\
\hline Ktm & $6.839 .982,6$ & $7.957 .595,5$ & $9.248 .558,6$ \\
\hline $\mathrm{Kps}$ & $4.345 .188,9$ & $4.936 .311,0$ & $5.588 .994,5$ \\
\hline Brsl & $1.946 .239,4$ & $2.221 .436,9$ & $2.535 .924,0$ \\
\hline Brt & $2.089 .456,3$ & $2.354 .223,1$ & $2.697 .983,9$ \\
\hline Pky & $3.107 .861,5$ & $3.614 .155,0$ & $4.140 .535,7$ \\
\hline \multicolumn{4}{c}{ PDRB ADHB/Kapita (Rp) } \\
\hline Kbr & $17.763 .485,6$ & $19.072 .710,1$ & $21.393 .509,0$ \\
\hline Ktm & $18.595 .651,1$ & $21.234 .069,8$ & $24.309 .971,8$ \\
\hline Kps & $13.189 .181,1$ & $14.973 .854,9$ & $16.675 .203,1$ \\
\hline Brsl & $15.864 .357,6$ & $17.877 .472,4$ & $20.093 .370,0$ \\
\hline Brt & $17.345 .932,4$ & $19.348 .612,6$ & $21.896 .582,2$ \\
\hline Pky & $14.492 .107,7$ & $16.312 .161,0$ & $18.429 .985,0$ \\
\hline Keterangan
\end{tabular}

Keterangan: Kbr adalah singkatan dari Kotawaringin Barat, Ktm singkatan dari Kotawaringin Timur, Kps singkatan dari kapuas, Brsl singkatan dari Barito Selatan, Brt singkatan dari Barito utara, dan Pky singkatan dari Palangkaraya (Buletin Bank Indonesia, 2012).

Hubungan antara hadirnya pola-pola perkebunan besar kelapa sawit dengan nilai PDRB sebagai ukuran produktivitas seluruh barang dan jasa adalah ditunjukkan dengan adanya dukungan perbankan pada sektor-sektor usaha unggulan yang ada di Kalimantan Tengah. Salah satunya adalah pada penyaluran kredit-kredit investasi di sektor usaha pertanian, khususnya subsektor perkebunan di Kotawaringin Timur.

Selama kurun waktu tahun 2011 angka penyaluran kredit investasi BPD (Bank Pembangunan Daerah) Kalteng terhadap 
usaha unggulan, khususnya subsektor perkebunan kelapa sawit merupakan angka yang tertinggi. Dari seluruh kredit usaha subsektor perkebunan sawit yang disalurkan, 86,6\% merupakan kredit investasi, dan 87,3\% di antaranya di salurkan di Kotawaringin Timur (Buletin Bank Indonesia, 2012:27 dan Badan Pusat Statistik Daerah Kalimantan Tengah, 2012). Nilai kredit investasi pada subsektor perkebunan yang disalurkan BPD Kalteng ini tentu sudah dapat mengindikasikan bahwa nilai PDRB atau laju dari pertumbuhan ekonomi Kotawaringn Timur pada saat itu memang sejalan dengan geliat upaya pengembangan dan perluasan sektor perkebunan besar kelapa sawit yang dilakukan.

Akan tetapi, fenomena yang justru bertolak belakang dari geliat petumbuhan ekonomi Kotawaringin Timur saat itu adalah kontribusinya terhadap angka penduduk miskin di Provinsi Kalimantan Tengah. Kontribusi angka penduduk miskin Kotawaringin Timur terhadap total jumlah angka penduduk miskin di Kalimantan Tengah pada tahun 2010 adalah sekitar 18,9\% (Buletin Bank Indonesia, 2012:27 dan Badan Pusat Statistik Daerah Kalimantan Tengah, 2012: 20). Angka kemiskinan penduduk Kotawaringin ini tentu terbilang cukup besar dan ironis jika melihat ada 14 kabupaten kota di Kalimantan Tengah. Artinya, geliat pengembangan dan perluasan-perluasan perkebunan kelapa sawit di Kotawaringin Timur pada tahun 2010 ini ternyata juga diikuti oleh dua sisi dampaknya yang bertolak belakang atau paradoks. Pertama, adalah angka pertumbuhan ekonomi yang tinggi dan, kedua kontribusi dari jumlah angka kemiskinannya yang juga tinggi (Buletin Bank indonesia, 2012: 20).

Begitu pesatnya pertumbuhan ekonomi di satu sisi, dan tingginya kontribusi angka kemiskinan di sisi yang lain, merupakan gambaran lain dari perubahan akibat hadirnya pola-pola perkebunan besar kelapa sawit di
Kotawaringin Timur. Pola-pola perubahan yang sama ini juga terjadi pada komunitaskomunitas di sekitar areal perkebunan. Baik menyangkut dampaknya yang positif di satu sisi, dan juga sebaliknya pada sisi yang lain. Proses-proses adaptasi dalam konteks perubahan ini tentu menjadi bagian dari cara masyarakat selama ini menyikapi perubahan-perubahan yang terjadi.

\section{Pola Adaptasi Masyarakat}

Sebagaimana telah dijelaskan, terdapat dua bentuk perubahan yang dirasakan langsung oleh masyarakat terkait dengan kehadiran pola-pola perkebunan besar kelapa sawit di Kotawaringin Timur. Pertama yaitu perubahan yang menyangkut fungsi kawasan, dan kedua yaitu struktur kewilayahan beserta ruang-ruang kelola masyarakatnya.

Terkait dengan dengan hal itu, harus diakui bahwa hadirnya pola-pola perkebunan besar ini sejak awal memang tidak memberikan banyak pilihan bagi sebagian masyarakat di sekitar. Terutama bagi sebagian dari mereka yang terbiasa dengan pola-pola subsistensi melalui pengelolaan dan pemanfaatan sumber daya alam dan lahan. Sementara pada saat yang sama sebagian mereka justru belum mampu berdaptasi dengan kondisi-kondisi perubahan yang terjadi. Sehingga dari mereka ternyata kerap melakukan ekspansi terhadap areal-areal lahan kebun milik perusahan, mengajukan tuntutan ganti kerugian lahan, dan bahkan juga melakukan usaha-usaha pencurian buah sawit dari lahan-lahan kebun perusahaan. Dalam kasus-kasus seperti ini, kesan yang lalu muncul adalah anggapan bahwa apa yang mereka lakukan merupakan bagian dari pragmatisme untuk memeroleh keuntungan dari aktivitas-aktivitas perkebunan yang terjadi.

Sesungguhnya tidak juga seperti demikian. Karena yang terjadi justru adalah 
pihak perusahaan yang kerap kali tidak mengindahkan keberadaan masyarakat di sekitar. Tidak semata sebagai entitas sosial dan ekonomi. Namun juga sebagai entitas budaya yang sejatinya memiliki tradisi dan kultur pengelolaan lahan yang relatif berbeda. Karena harus mengikuti polapola perubahan yang ada maka persoalanpersoalan yang sama pada gilirannya akan selalu kerap muncul secara akumulatif tatkala perubahan justru tidak memberikan ruang yang sama bagi terjadinya proses adaptasi oleh masyarakat.

Akan halnya pola-pola adaptasi yang dilakukan masyarakat, secara umum terbagi dalam tiga katagori. Terutama melalui pengorganisasian lingkungan sekitar beserta aktivitas-aktivitasnya secara mandiri sesuai dengan sumber daya yang dimiliki.

Katagori dari pola-pola adaptasi tersebut antara lain adalah pertama, menjadi pekerja di perusahaan pada bidang yang tidak harus bersaing dengan pekerja dari luar daerah, khususnya Pulau Jawa, kedua yaitu menjadi penyedia dari jasa angkutan dalam aktivitas-aktivitas yang ada di perusahaan dan ketiga atau terakhir adalah dengan cara mengembangkan potensi dari peluangpeluang yang muncul oleh karena adanya aktivitas di sekitar perusahaan. Dalam hal ini termasuk mengembangkan potensi lahan-lahan pekarangan sekitar yang masih mereka miliki.

Secara ekologi kultural, salah satu keterbatasan penduduk asli atau masyarakat di sekitar hutan adalah kultur etos kerja yang terbentuk oleh karena ketersediaan sumber-sumber daya alam yang sangat melimpah. Alam sebagai sumber utama mata pencaharian, kecuali saat maraknya kasus pengusahaan kayu-kayu hutan cenderung akan mereka manfaatkan, gunakan dan kelola secara subsisten sebatas untuk memenuhi kebutuhan hidup sehari-hari. Sehingga hampir tidak ada tekanan yang muncul oleh karena adanya persaingan bertahan hidup di antara mereka. Kondisi ini tentunya membuat sebagian mereka menjadi tidak terbiasa dengan jenis-jenis pekerjaan yang tidak semata membutuhkan keahlian, namun juga kedisiplinan waktu dan kerja yang tinggi. Oleh sebab itu, hampir semua bentuk pekerjaan yang berhubungan langsung dengan budidaya tanaman kelapa sawit akan selalu didominasi oleh para pekerja dari luar daerah, khususnya pulau Jawa. Sementara mereka yang memilih untuk bekerja pada perusahaan, maka pekerjaan yang dipilih adalah yang relatif tidak menuntut adanya kedisiplinan kerja dan waktu yang tinggi. Jenis-jenis pekerjaan yang memang relatif tidak menuntut adanya bentuk persaingan, terutama dengan para pendatang yang dikenal memiliki etos budaya kerja, ulet dan juga tahan banting. Jenis pekerjaan dimaksud antara lain adalah; satpam, mandor, pembantu administrasi, penjaga kebun, supir, petugas kebersihan, dan sebagainya. Berbeda dengan mereka para pekerja dari luar daerah, khususnya pulau Jawa yang hampirhampir mendominasi setiap jenis pekerjaan tertentu yang membutuhkan tingkat kedisiplinan waktu, ketekunan dan juga keuletan yang tinggi. Seperti saat blocking area atau pembukaan lahan, pada saat proses penanaman, pemupukan, pemeliharaan, hingga pada saat panen atau pengangkutan buah hasil panen dan sebagainya.

Selain memilih pada jenis-jenis pekerjaan tertentu tersebut, ada juga masyarakat yang menyesuaikan diri atau beradaptasi dengan cara terlibat dalam aktivitas-aktivitas perkebunan di perusahaan, namun dengan tidak menjadi tenaga pekerja. Mereka ini terlibat dalam aktivitas perusahaan dengan caran menjadi penyedia jasa angkutan. Khususnya jasa angkutan seperti pupuk, buah hasil panen, barang kebutuhan, baik kebutuhan kantor maupun karyawan dan lain sebagainya. Peluang-peluang seperti ini memang cukup terbuka, karena tidak semua perusahaan itu memiliki atau menyediakan 
sarana angkutan secara penuh, kecuali khusus untuk angkutan para karyawan, baik dari mes penginapan ke areal-areal lahan kebun ataupun sebaliknya. Sejumlah perusahaan perkebunan selama ini memang lebih banyak menggunakan pihak ketiga untuk memenuhi sarana angkutan yang dibutuhkan dalam memobilisasi kebutuhan perusahaan.

Mereka yang bergabung sebagai penyedia jasa angkutan perusahaan, pada umumnya adalah mereka yang sejak awal telah memiliki kendaraan angkutan, terutama ketika aktivitas-aktivitas pengusahaan kayu di hutan masih marak terjadi. Meski memang tidak semua yang menjadi penyedia jasa angkutan perusahaan ini adalah masyarakat yang berasal dari lokasi-lokasi sekitar perkebunan. Beberapa di antaranya ada juga yang berasal dari luar wilayah. Oleh karena status dan jabatannya dalam pemerintahan, lembaga-lembaga adat, kepemudaan atau lembaga sosial dan sebagainya, mereka kemudian memiliki posisi tawar dan pengaruh yang relatif kuat terhadap perusahaan. Meski tidak semua, namun sebagian dari mereka yang memiliki posisi tawar tersebut kemudian memanfaatkannya dengan cara bergabung atau terlibat menjadi penyedia-penyedia jasa angkutan di perusahaan.

Selain itu, ada juga kelompok masyarakat yang beradaptasi dengan caracaranya yang relatif berbeda. Mereka ini beradaptasi dengan cara memanfaatkan dan mengembangkan peluang dari segenap potensi yang ada di sekitar lokasi pemukiman dan perkebunan. Terutama pada lokasi-lokasi strategis yang menjadi akses bagi semua aktivitas di perkebunan.

Jumlah mereka ini sepertinya menjadi yang terbesar dari sejumlah masyarakat yang mampu berdaptasi terhadap kehadiran dari perkebunan-perkebunan besar kelapa sawit saat ini. Karena cara-cara yang mereka lakukan sangatlah beragam. Berikut adalah beberapa cara adaptasi yang dominan mereka lakukan. Pertama adalah dengan mengambil perannya sebagai pihak penyedia atau penjual barang kebutuhan para pekerja yang relatif tidak disediakan perusahaan. Sekalipun mungkin beberapa jenis kebutuhan dimaksud memang telah tersedia atau disediakan oleh pihak koperasi perusahaan, namun jumlah dan jenisnya dianggap masih kurang memadai atau kurang lengkap sesuai dengan kebutuhan para pekerja yang terus berkembang. Sehingga mereka kemudian mengambil peran dengan caranya menyediakan barang-barang kebutuhan tersebut melalui warung atau toko-toko kelontong yang telah berdiri atau mereka dirikan sendiri di lokasi-lokasi strategis dan mudah untuk dijangkau. Biasanya di lokasilokasi persimpangan jalan tertentu yang menjadi akses semua aktivitas, atau sekedar menjajakan di rumah-rumah sederhana yang berada di sekitar lokasi perkebunan. Kedua adalah dengan memanfaatkan lahan-lahan pekarangan yaitu dengan cara mengembangkan budidaya tanaman usia pendek, seperti sayur-sayuran, palawija dan juga buah-buahan usia pendek. Hasil dari budidaya mereka ini kemudian dipasok atau dijual ke toko-toko kelontong atau warung yang memang telah banyak berdiri atau dibangun di dekat sekitar lokasi areal perkebunan. Dengan kata lain, selain menjual jenis barang-barang kebutuhan sekunder tertentu, banyak dari toko-toko dan warung sekitar juga menyediakan barang kebutuhan pokok sehari-hari atau komoditas pangan yang dibudidayakan oleh masyarakat sekitar perkebunan.

Sementara yang ketiga adalah mereka yang ikut membudidayakan komoditas tanaman yang sama atau tanaman sejenis yang dikembangkan oleh perusahaan, yaitu kelapa sawit. Selain dilakukan dengan caracara yang sederhana, jumlah dan luas lahannya juga sering kali terbilang sangat kecil dan terpisah-pisah antar satu sama lain. 
Karena sifatnya ini hanya perorangan. Bukan kelompok sebagaimana plasma dalam pola PIR (Perkebunan Inti Rakyat) dan KKPA. Karena sebagian besar areal lahan-lahan perkebunan kelapa sawit di Kotawaringin Timur ini sendiri, baik itu swasta maupun negara memang dibangun dan berkembang pada saat penerapan pola KKPA, yaitu Kredit kepada Koperasi Primer untuk anggota yang juga menurut banyak infomasi pada saat itu konon penuh dengan masalah.

Selain masuknya arus modal invenstasi, faktor-faktor produksi dan penyerapan tenaga kerja, salah satu konsekuensi dari hadirnya pola-pola perkebunan besar kelapa sawit adalah adanya infrastruktur jalan di dalam atau sekitar areal perkebunan. Infrastruktur jalan-jalan perkebunan yang dibangun ini pada gilirannya justru telah turut membuka akses ke wilayah-wilayah pemukiman sekitar areal perkebunan. Sekalipun jalan-jalan ini dibangun dalam tujuan dan kepentingan yang berbeda, namun keberadaannya tentu menjadi bagian dari dampak yang menguntungkan masyarakat sekitar area perkebunan. Tidak hanya persoalan aksesibilitas, namun juga meningkatnya aktivitas-aktivitas sosial ekonomi yang terjadi di sekitar areal lokasi perkebunan. Pada gilirannya, kondisi seperti ini tentu telah turut memberikan adanya peluang dan juga kesempatan bagi berkembangnya partisipasi ekonomi masyarakat sekitar melalui aktivitas-aktivitasnya yang terjadi. Sebagai contoh adalah daerahdaerah seperti Simpang Bakal, Simpang Sebabi, Munduk dan sebagainya yang justru mulai berkembang setelah maraknya aktivitas-aktivitas perkebunan sawit di Kotawaringin Timur.

Menariknya, hampir dari semua pedagang di lokasi-lokasi yang saat ini telah berkembang menjadi pusat-pusat aktivitas pasar tersebut adalah penduduk lokal dari sekitar areal perkebunan. Artinya, dalam konteks yang berbeda dari kondisi dampak ekologis, hilangnya hak akses kelola atas ruang kawasan tradisional, dan punahnya tradisi-tradisi pengelolaan sumber-sumberdaya alam dan lahan, sebagian dari mereka justru mampu melakukan proses adaptasi terhadap perubahan-perubahan sebagai akibat dari beralihnya fungsi kawasan yang terjadi selama ini.

\section{PENUTUP}

Konversi atau pengalihan fungsi kawasan memang selalu membawa dampak yang sangat signifikan bagi masyarakat. Karena itu menyangkut perubahan sumbersumberdaya alam dan lahan yang selama ini diakses dan dikelola oleh masyarakat. Tetapi tidak semua dampak akan berhenti pada hitam atau putih, dus negatif atau positif. Adakalanya dampaknya itu merugikan terutama dalam kurun waktu tertentu. Tetapi ada kalanya juga justru menguntungkan dalam kurun waktu tertentu lainnya yang berbeda. Demikian juga yang terjadi dengan dampak perubahan sebagai akibat pengalihan fungsi kawasan di Kotawaringin Timur, Kalimantan Tengah.

Pada masa ketika pengusahaan kayukayu hutan masih kerap terjadi misalnya, tidak sedikit dampak yang ditimbukan itu justru menumbuhkan geliat ekonomi pasar di masyarakat. Meski itu lebih banyak terjadi pada sektor informal. Dari aktivitas pasar-pasar di Kota Sampit sebagai Ibu Kota Kotawaringin Timur hingga ke wilayah-wilayah pedalaman. Tidak hanya itu, geliat dari ekonomi yang terbentuk juga ditunjukkan dengan banyaknya fasilitas perbankan yang tumbuh dan berkembang di Kota Sampit saat itu. Tetapi yang ternyata cukup ironis adalah selain dampak ekologis kerusakan-kerusakan hutan yang ditimbulkan, aktivitas-aktivitas pengusahaan kayu hutan ini justru tidak memiliki pengaruh signifikan terhadap PAD atau pendapatan asli daerah Kotawaringin 
Timur. Karena sebagian dari pengusahaan hutan ini memang terjadi secara ilegal.

Seiring dengan adanya larangan dan penertiban pengusahaan hutan, hadirnya perkebunan-perkebunan kelapa sawit kemudian menandai adanya perubahan-perubahan baru. Dari era pengusahaan hutan, ke era perkebunan kelapa sawit. Namun konsesi-konsesi lahan perkebunan yang ada juga memunculkan bentuk persoalan yang relatif sama, bahkan jauh lebih rumit dibanding dengan era pengusahaan hutan sebelumnya. Terutama menyangkut fungsifungsi kawasan, hilangnya akses atas ruang kelola hidup masyarakat dan tradisi-tradisi pengelolaan dan pemanfaatan sumber-sumberdaya alam dan lahan sekitar. Hal inilah yang menjadikan pada awal-awal dari kehadirannya, perkebunan-perkebunan sawit justru kerap kali membuat konflik-konflik dengan masyarakat sekitar.

Sekalipun demikian, akibat dari masuknya modal investasi, faktor-faktor produksi dan juga penyerapan tenaga kerja, kehadiran perkebunan-perkebunan sawit justru membuat nilai PDRB atas dasar harga berlaku Kotawaringin Timur menjadi yang paling tinggi se Kalimantan Tengah. Besaran PDRB Kotawaringin Timur pada tahun 2011 misalnya, ternyata mencapai 9,25 triliun rupiah, atau setara dengan 20,71\% dari jumlah nilai total PDRB seluruh kabupaten kota se-Kalimantan Tengah. Meski pada tahun 2010, kontribusi angka kemiskinan di Kotawaringin Timur juga menjadi yang tertinggi, yaitu sekitar 18,9\% dari 15 kabupaten kota seKalimantan Tengah saat itu.

Tingginya angka PDRB atau pertumbuhan ekonomi pada satu sisi dan kemiskinan pada sisi yang lain tentu telah menggambarkan adanya distribusi pendapatan yang memang tidak merata. Hal ini karena pola perubahan yang ada memang tidak memberikan ruang akses yang sama bagi proses adaptasi di masyarakat.
Namun kondisi seperti ini tentu tidak berlaku bagi sebagian mereka yang secara ekologi kultural justru mampu melakukan proses adaptasi terhadap perubahan-perubahan yang terjadi. Ekologi kultural dimaksud adalah kemampuan ontologis untuk memahami dan mengorganisasikan kondisi lingkungan beserta aktivitas-aktivitasnya yang terjadi.

Terdapat tiga pengelompokan pola aktivitas sebagai cara adaptasi yang dilakukan masyarakat sekitar perkebunan. Pertama adalah dengan menjadi pekerja di perusahaan pada bidang-bidang tertentu yang tidak harus bersaing dengan para pekerja dari luar-luar daerah, khususnya dari Pulau Jawa.

Alam dengan sumberdayanya yang melimpah memang kerap kali memunculkan budaya pengelolaan sebatas untuk memenuhi kebutuhan sehari-hari atau subsisten. Sehingga memang hampir-hampir tidak ada tekanan yang muncul oleh karena adanya persaingan untuk bertahan hidup. Pada gilirannya sebagian dari mereka ini kemudian menjadi tidak terbiasa dengan jenis-jenis pekerjaan yang relatif tidak saja membutuhkan keahlian, tetapi juga kedisiplinan waktu dan etos kerja yang tinggi.

Kedua adalah dengan menjadi pihak penyedia jasa angkutan dalam aktivitasaktivitas yang terjadi pada perusahaan. Seperti angkutan pupuk, hasil panen, limbah sawit, angkutan barang kebutuhan, baik kebutuhan kantor maupun para pekerjanya dan sebagainya. Peluang-peluang seperti ini diperoleh karena memang tidak semua perusahaan itu memiliki atau menyediakan sarana angkutan yang lengkap. Sementara sebagian dari mereka justru telah memiliki sarana angkutan sekaligus juga pengalaman sejak masih maraknya pengusahaan-pengusahaan kayu di hutan.

Pola adaptif terakhir atau ketiga adalah dengan cara mengembangkan potensi dari 
peluang-peluang yang muncul oleh karena adanya aktivitas perusahaan. Pola adaptif dimaksud ini antara lain adalah dengan cara 1) mengambil peran dan fungsi sebagai penyedia atau penjual barang-barang kebutuhan para pekerja perusahaan, 2) mengembangkan budidaya jenis tanaman usia pendek; seperti sayur-sayuran, palawija atau buah-buahan usia pendek yang akan di pasok atau dijual kepada pihak penyedia, dan 3) membudidayakan komoditas tanaman sejenis yang dibudidayakan oleh perusahaan, yaitu kelapa sawit.

Pola-pola adaptasi yang terakhir ini ternyata juga menjadi aktivitas yang paling sering banyak dilakukan oleh masyarakat sekitar. Sebab apa yang mereka lakukan ini berasal dari apa yang relatif masih mereka miliki hingga saat ini yaitu pengetahuan lokal, pengalaman empiris, dan juga kemampuan mengelola lingkungan beserta aktivitas-aktivitasnya yang terjadi. Artinya, dampak perubahan dari pengalihan fungsi kawasan ini ternyata tidak akan selamanya selalu berhenti pada hitam dan putih, atau negatif dan positif. Ia akan selalu berubah seiring dengan waktu dan cara masyarakat dalam memahami dan mengorganisasikan lingkungan sebagai cara dari mereka beradaptasi terhadap perubahan-perubahan yang terjadi.

Mengacu pada pembahasan dan simpulan tersebut, maka dipandang perlu rekomendasi sebagai salah satu upaya pelaksanaan pelestarian, pengembangan dan perlindungan aspek-aspek tradisi dan kesejarahan yang terkait dengan pemilikan dan kepemilikan lahan oleh masyarakat sekitar areal perkebunan. Pertama, perlu adanya kajian lebih mendalam mengenai dampak pengalihan fungsi kawasan terhadap aksesibilitas lahan dan proses-proses adaptasinya yang dilakukan masyarakat. Kedua, perlu adanya kajian strategis dalam upaya penyusunan kebijakan khusus yang lebih memperhatikan dampak dari hilangnya aksesibilitas atas ruang-ruang kelola hidup pada masyarakat sekitar areal perkebunan. Sehingga persoalan-persoalan sengketa lahan, klaim dan tuntutan ganti rugi yang selama ini masuk ke arbitrase formal dan informal akan semakin cepat dan mudah untuk diselesaikan, serta menguntungkan bagi kedua belah pihak, masyarakat sekitar dan pihak perusahaan. Sementara terakhir atau ketiga adalah perlu adanya kajian inventarisasi potensi sosial ekonomi dan sosial budaya yang muncul oleh karena peluang akibat dari hadirnya pola-pola ekspansi perkebunan kelapa sawit saat ini. Sehingga kehadiran atas ekspansinya tidak lagi menjadi momok bagi masyarakat di sekitar areal perkebunan. Terutama melalui pola-pola pengetahuan dan kearifan lokal masyarakatnya.

\section{DAFTAR SUMBER}

Basyar, Abdul Hakim. Evaluasi Penerapan Kebijakan Konversi Hutan untuk Perkebunan Kelapa Sawit" diunduh dari https://www.bappenas.go.id/ pada tanggal 28 Mei 2017.

Buletin Bank Indonesia. 2012. Kajian Ekonomi Regional Provinsi Kalimantan Tengah. Triwulan III.

Burger, P.L., dan Thomas Luckman. 1990. Judul (Tafsir Sosial atas Kenyataan: risalah tentang Sosiologi Pengetahuan). Terjemahan Hasan Basri. Jakarta: LP3ES.

Haviland, William A. 1993. Antropologi, Jakarta: Erlangga.

Kamus Besar Bahasa Indonesia dalam Jaringan, diunduh dari https://kbbi. web.id/adaptasi, pada 10 Juli 2017.

Kaplan, David dan Robert A. Manners. 2002. Teori Budaya. Terjemahan Landung Simatupang, Yogyakarta: Pustaka Pelajar. 
Keesing, Roger M. 1981. Antropologi Budaya: Suatu Perspektif Kontemporer. Terjemahan Samuel Gunawan. Jakarta: Erlangga. . 1997. Pengantar Antropologi; PokokPokok Etnografi. Jakarta: Rineka Cipta.

Koentjaraningrat. 1995. Manusia Dan Kebudayaan Di Indonesia. Jakarta: Djambatan.

Meilantina, Mayang. 2006. Integrasi Hak Pemanfaatan Tanah Masyarakat Dayak dalam Rencana Tata Ruang Wilayah Kabupaten; Studi di Kabupaten Gunung Mas, Kalimantan Tengah. Bogor; Centre for International Forestry Research diunduh dari www.cifor. org/publications/pdf_files/Books/ BMayang0601.pdf, pada tanggal 29 Januari 2017.

Obidzinski, Krystof et al. 2006. Penyelundupan Kayu di Indonesia, Masalah Genting ataukah Berlebihan; Pembelajaran Pengaturan Hutan dari Kalimantan. CIFOR, Center fo Internatonal Forestry Research, Jakarta; Harapan Prima.

Soekanto, Soerjono, 1993. Kamus Sosiologi. Jakarta; Raja Grafindo Persada.

Soekanto, Soerjono, 2000. Sosiologi Suatu Pengantar. Jakarta; Raja Grafindo Persada.
Subiyantoro, Muh. Edi, et al. (ed.). dst 2015. Statistik Perkebunan Indonesia, Kelapa Sawit, 2014 - 2016. Direktorat Jenderal Perkebunan diunduh dari http://ditjenbun.pertanian.go.id/ tinymcpuk/gambar/file/statistik/ pada tanggal 18 Agutus 2017.

Tim Penyusun. 2003. Peraturan Daerah Provinsi Kalimantan Tengah Nomor 8 Tahun 2003 tentang Rencana Tata Ruang Wilayah Provinsi kalimantan Tengah. Palangkaraya: Dokumen Badan Perencanaan dan Pembangunan Daerah Kalimantan Tengah.

Tim Penyusun. 2012. Kalimantan Tengah dalam Angka. Palangkaraya: Badan Pusat Statistik Kalimantan Tengah.

Wawancara. HSN (mantan pekerja rintisan kebun. Kotawaringin Timur, 7 Juli 2013

Wawancara. HN (anggota Kepolisian Daerah). Kotawaringin Timur, 8 Juli 2013.

Wawancara. BS (demang). Kotawaringin Timur, 7 Juli 2013. 